\title{
Overtourism: The Negative Impacts of Domestic Beach Tourism on the Residents of Alexandria, Egypt
}

\section{Rania Ragab}

Assistant Lecturer- Tourism Studies Department

Faculty of Tourism and Hotels, Alexandria University, Egypt

\author{
Abeer Attia \\ Professor- Tourism Studies Department \\ Faculty of Tourism and Hotels, Alexandria University, Egypt \\ Nashwa Fouad \\ Professor- Tourism Studies Department \\ Faculty of Tourism and Hotels, Alexandria University, Egypt
}

\begin{abstract}
Overtourism is a phenomenon that has spread in many popular destinations such as Venice, Barcelona, Dubrovnik, and Amsterdam, and has been greatly aggravated, leading to demonstrations and protests by residents. Despite the increasing importance of this issue, overtourism is not a new phenomenon. Since the 60s, some authors have mentioned the negative impacts of the increasing tourist demand on residents in many destinations. The aim of this research is to investigate the negative impacts of tourism on the local community in order to provide some recommendations to improve the local residents' quality of life and as a result decrease anti-tourism sentiments and increase the quality of tourist experience in Alexandria. The interview conducted with the director of the Administration Center for Tourism and Summer Resorts and the
\end{abstract} questionnaire distributed among the residents, reflect their feedback concerning the unwanted behaviors of local tourists who come from the different governorates of Egypt to Alexandria during the summer months to spend their holidays on the beaches, as well as the damage resulting from the excessive number of tourists on the infrastructure and the beaches. In addition, the findings approved that most of the residents prefer to take their holidays outside Alexandria. Finally, the research provides a variety of recommendations suggested to avoid the negative impacts on the local community and to raise the awareness of domestic tourists.

Keywords: Overtourism, residents, beaches, domestic tourists, Alexandria 


\section{Introduction}

Overtourism, also known as "Overcrowding" and "Tourism-Phobia"(Stanchev \&Turisme, 2018; Weber, et al., 2017; Milano et al., 2019), has become an unfavorable feature in a lot of popular destinations in almost thirteen European countries, for instance; Venice Barcelona- Prague- Santorini- Amsterdam Dubrovnik- Malloca- Berlin-Rome (Goodwin, 2017; Weber, et al., 2017; Martín, et al., 2018; Stanchey \&Turisme, 2018; Almeida, et al., 2019).It has emerged as a new concept in the past few years (Sziva et al., 2019; Goodwin, 2017). Generally, the degree of a destination's development causes an increase in the interferences in the local lifestyle (Martín, et al, 2018). Today, some forms of tourism dislodge residents from their regions and harm the environment. This situation has led to the resentment among local community towards tourism (Coldwell, 2017; Almeida, et al., 2019; Sziva et al., 2019). Consequently, The UNWTO has asked the local authorities to exert efforts to manage the growth of the tourism sector in a sustainable manner (Coldwell, 2017).

Tourism is considered one of the strategic sectors of the Egyptian economy. Alexandria is a fundamental tourist destination for international and domestic market, because of its historical sites and natural attractions. It is distinguished by its beaches from AlMa'amora eastern to Al-Agamy at the west, with about $24 \mathrm{~km}$ long, and due to its perfect geographic location and its natural resources it became the largest port in the Mediterranean and the Middle East, the second largest city in Egypt and has acquired popularity among the Arabic countries, as well as the other Egyptian governorates as a good summer resort. Therefore, it suffers, as many other tourist destinations in summer, from overtourism especially from domestic tourists (Alexandria Portal, 2014). It receives large domestic tourists and day visitors with the main purpose of visiting its beaches that overlook the cliffs of the Mediterranean. There are main factors that contribute to the overcrowding in Alexandria are (Orabi, 2017):

$\circ$ The city is considered a local destination for Egyptians and the city also has the trait of a family resort.

ㅇ It is the nearest coastal city to many rural cities (governorates) which are the main tourist markets.

○ The city's mental image for domestic tourists is closely related to beach tourism.

Thus, this study aims to investigate the negative impacts of domestic beach tourism on Alexandrians and provide some recommendations to improve the residents' quality of life and as a result decrease the antitourism sentiments and increase the quality of tourist experience on the other hand.

\section{Literature Review}

\subsection{Definition of Overtourism}

The study of Goodwin (2017, p.1) describes overtourism as "destinations where hosts or guests, locals or visitors, feel that there are too many visitors and that the quality of life in the area, or the quality of the experience has deteriorated unacceptably". According to Milano, et al. (2018, p. 2) overtourism is defined as "the excessive growth of visitors leading to overcrowding in areas where residents suffer the consequences of temporary and seasonal tourism peaks, which have enforced permanent changes to their lifestyles, access to amenities and general well-being". Additionally, overtourism is "a situation where either local people or the 
tourists feel that the place is just over visited and that it is changing its character. So, for the tourist it loses its authenticity and for the local people it just causes irritation and annoyance" (Taiminen, 2018, p.9).

Coldwell (2017) states that over-tourism has aggravated because of the mismanagement. Generally, the tourism sector requires sustainable tourism policies, practices and the engagement of all parties including the national, in addition to the local governments and private sector, local communities and tourists. Thus, treating this issue requires a sustained and comprehensive tourism planning at national, regional and local levels which must include a wide range of measures and actions (Martins, 2018). This will improve the life of residents and make them more welcoming to tourists. At the same time, this will increase the economic benefits resulting from tourism and enhance the quality of tourists' satisfaction.

\subsection{Overtourism troubles}

Overtourism, as a term, represents negative aspects of tourism, which are major reasons for dissatisfaction amongst residents (Sziva et al., 2019). According to WTTC (2017) there are four types of troubles associated with over-tourism or tourist overcrowding: -

a- Alienation of local residents: may be a result of rising rents, noise, crowding, increase of prices, the pressure on daily life, the change of place features, as well as the leakage of economic benefits of tourism that can further support resident discontent.

b- Degradation of tourist experience: in many places, the tourist experience itself is degraded due to queues, crowding, or harassments. c- Overload on local infrastructure: the pressure on infrastructure and services used by tourists, such as; hygiene and transport. In addition, tourists create challenges in terms of energy consumption and waste management.

d- Damage to nature: through pollution, overuse of natural resources such as water, beaches, forests, and wildlife.

Some destinations face one or more of these issues at the same time, but once these regions determine their most important troubles, they can select the most convenient solutions (WTTC, 2017).

\subsection{Response to Overtourism}

It is important to develop and implement a crucial plan to mitigate the negative effects of overtourism. Furthermore, it is important to monitor the plan for its feasible and effective implementation (Martins, 2018). WTTC Report (2017) highlights four required practices that should be implemented regardless of whether a destination or a visitor attraction is facing overcrowding:

a- Building a comprehensive database, updating it regularly and developing the analytic capabilities to improve the development strategies.

b- Performing long-term planning to encourage sustainable growth and mitigate or even ban the overtourism.

c- Involving all stakeholders (public, tourism authorities and private) to discuss troubles and find solutions.

d- Finding innovative approaches to encourage investments in infrastructure and sustainability ventures. 
Therefore, facing overtourism must be a priority for many destinations or attractions while selecting the suitable solutions for it (WTTC Report, 2017). For example, some areas have taken some measures to limit the effects of overtourism, including demarketing, increasing the current taxes or fees or imposing new taxes and penalties linked to local laws (WTTC Report, 2017; Peeters et al., 2018).

Besides, UNWTO recommended a number of certain methods for managing crowds in destinations, such as encouraging tourists to visit beyond the hot spot attractions, diversifying tourist products and activities, decreasing seasonality and addressing the demands and needs of the local community (Coldwell, 2017; Stanchev \& Turisme, 2018).

\subsection{Beach tourism in Alexandria}

Alexandria is considered as the principal seaside summer resort on the Mediterranean (Fig. 1) (Frihy, et al., 1996).

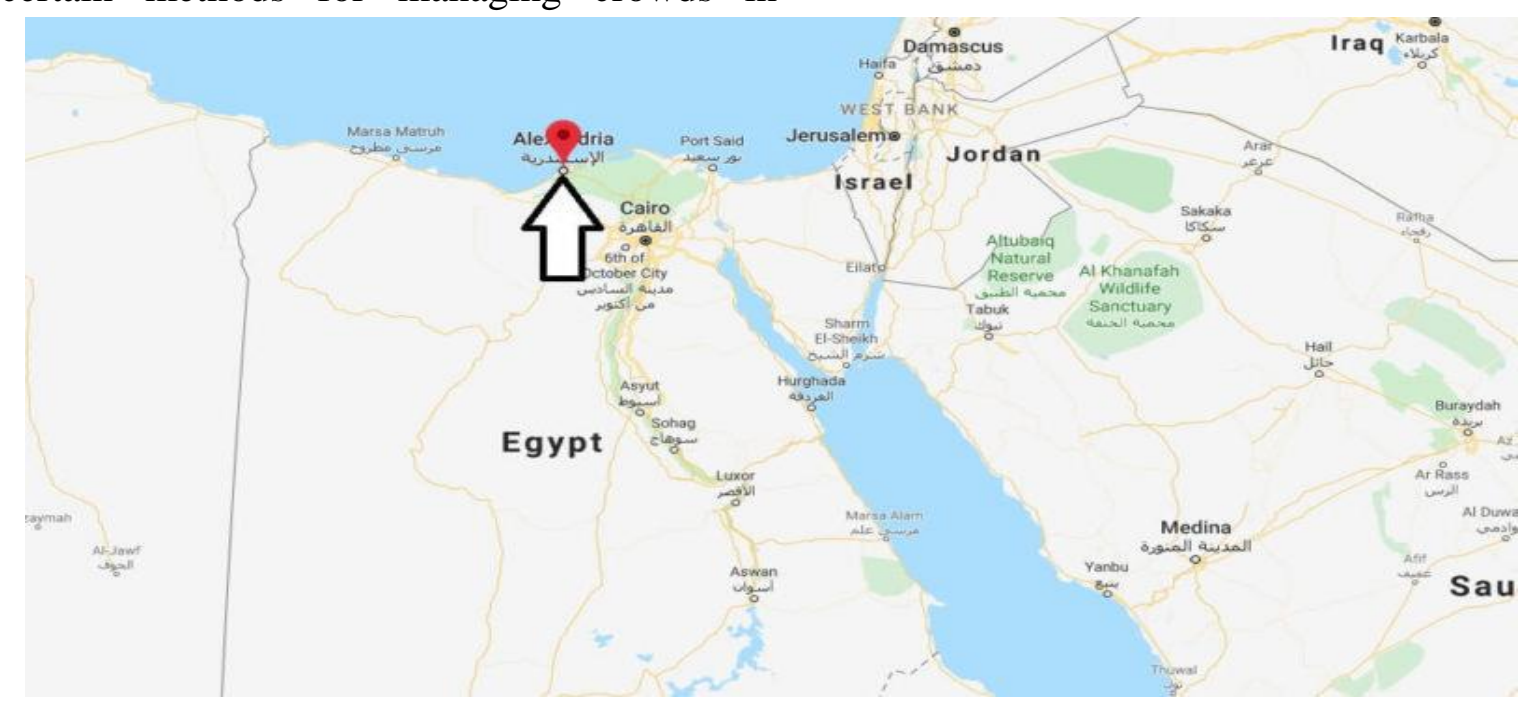

Figure (1): Alexandria Map

Source: Where is Map (2020)

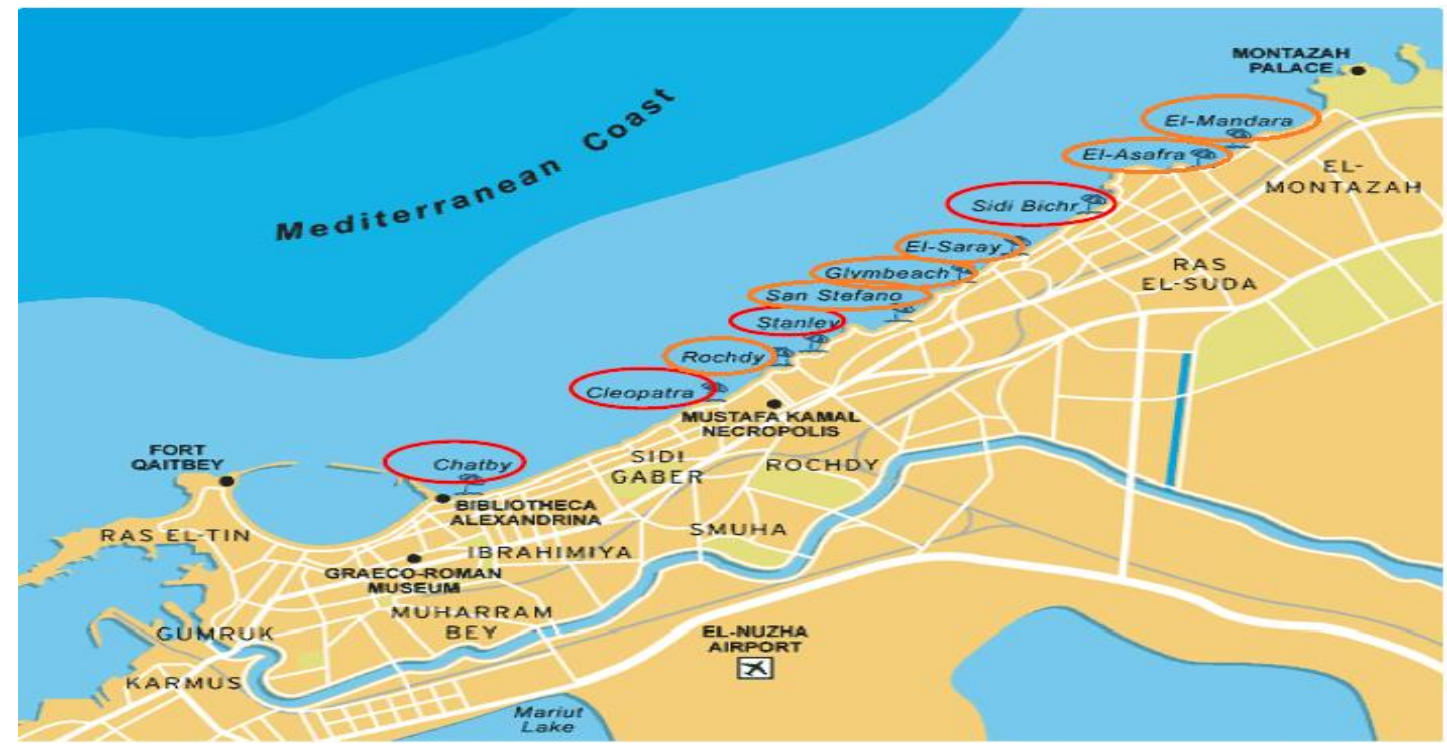

Figure (2): Main beaches in Alexandria

Source: Hussein (2013) 
Beaches extend for $50 \mathrm{~km}$ along the coast of the Mediterranean Sea from Abu Qir in the east to El-Agami in the west (Fig. 2) (Hussein et al., 2013). They have become one of the fastest growing attractions in the city as they offer opportunities for entertainment for domestic tourists and day visitors. These beaches are divided according to the level of service provided and prices into four categories; public beaches, service requested beaches, featured beaches and touristic beaches (see fig. 3) (the Administration Center for Tourism and Summer Resorts, 2019).Generally, the increasing demand for beaches resulted in changes in the environment involving above carrying capacity, crowding, damage of landscape and beaches; in addition to the negative impacts on the local residents (Prabpriree, et al., 2016; Milano, et al., 2018).

Table (1) beach categories in Alexandria

\begin{tabular}{|l|c|c|}
\hline \multicolumn{1}{|c|}{$\begin{array}{c}\text { Beach categories in } \\
\text { Alexandria }\end{array}$} & Number & \% \\
\hline Featured beaches & 21 & 35.6 \\
\hline Touristic beaches & 6 & 10.2 \\
\hline public beaches & 9 & 15.3 \\
\hline Service requested beaches & 23 & 38.9 \\
\hline Total & 59 & 100 \\
\hline
\end{tabular}

Source: The Administration Center for Tourism and Summer Resorts (2019)

\section{Research Method}

This study is based on a mixed methodology in order to realize the research objectives. Information was gathered through a questionnaire distributed online through the Facebook during the period from November 2019 to January 2020. The questionnaire aimed to investigate the negative impacts of tourism on the residents and their reactions towards overtourism in order to decrease their anti-tourism sentiments and increase the quality of tourist's experience in Alexandria.

Besides, a semi-structured interview was conducted with the head of the Administration Center for Tourism and Summer Resorts in Alexandria in order to evaluate the performance of beach management and to explore their future measures to cover the negative impacts of overtourism on the local residents. The interview questions revolved around 4 key axes including the management and monitoring of beaches, the handling of complaints, the future measures set to reduce congestion and to handle the unwanted behavior of tourists and improve the tourists' experience.

\section{Findings \& Discussions}

First, 226 questionnaires were obtained representing the residents of Alexandria. The results of the questionnaire's analysis showed that $68.6 \%$ of the respondents were females and $31.4 \%$ males. Most of them (84.1\%) with the age range from 18-35 years old.

Table (2) shows the location of the respondents' summer vacation

\begin{tabular}{|l|c|c|}
\hline \multicolumn{1}{|c|}{ The city } & Respondents & \% \\
\hline Marsa Matrouh & 81 & 35.8 \\
\hline North cost & 73 & 32.3 \\
\hline Sharm El-Shaikh & 30 & 13.3 \\
\hline Inside Alexandria & 29 & 12.8 \\
\hline Hurghada & 13 & 5.8 \\
\hline
\end{tabular}

Table 2 reveals that most of the residents spend their summer vacations outside the city. Specially, in Marsa Matrouh and the North Coast due to their geographical proximity. Whereas only $12.8 \%$ of the respondents spend their vacation inside Alexandria. 
Table (3) The frequency of spending the vacation outside Alexandria during the last10years

\begin{tabular}{|l|c|c|}
\hline Number of times & Respondents & $\mathbf{\%}$ \\
\hline 3 Times & 101 & 44.7 \\
\hline 5 Times & 46 & 19.9 \\
\hline 7 Times & 33 & 14.6 \\
\hline 10 Times & 47 & 20.8 \\
\hline
\end{tabular}

Table 3 shows that, in general, the respondents enjoy spending their vacation outside Alexandria during the past 10 years. $44.7 \%$ of them spent their vacations 3 times during the period and $20.8 \%$ of respondents travelled annually to other cities to enjoy their vacations. $19.9 \%$ of them travelled 5 times and the rest of the sample (14.6\%) travelled 7 times during the same period. These results reflect the unwillingness of the residents to spend their holidays inside Alexandria.

Table (4) shows the preferences of respondents regarding the types of Alexandria beaches

\begin{tabular}{|l|c|c|}
\hline \multicolumn{1}{|c|}{$\begin{array}{c}\text { Beaches } \\
\text { classification }\end{array}$} & Respondents & \% \\
\hline Featured beaches & 145 & 64.2 \\
\hline Touristic beaches & 67 & 29.6 \\
\hline $\begin{array}{l}\text { Public beaches } \\
\text { \&service requested } \\
\text { beaches }\end{array}$ & 14 & 6.2 \\
\hline
\end{tabular}

Table 4 highlights that most respondents prefer the featured beaches as day users to obtain a high-quality service, to maintain privacy, and to avoid inconveniences; while there are only $29.6 \%$ of them who prefer the touristic beaches because they are less expensive. However, they notice that the service provided is inappropriate and unsymmetrical with the paid value.
Table (5) the opinion of respondents concerning the shortcomings on Alexandria beaches

\begin{tabular}{|l|c|c|}
\hline \multicolumn{1}{|c|}{ Shortcomings } & Respondents & \% \\
\hline $\begin{array}{l}\text { Cleaning service isn't } \\
\text { available regularly }\end{array}$ & 146 & 64.6 \\
\hline $\begin{array}{l}\text { Lack of security to } \\
\text { prevent harassment } \\
\text { and disturbances }\end{array}$ & 113 & 50 \\
\hline Insufficient lighting & 57 & 25.2 \\
\hline Inappropriate toilets & 140 & 61.9 \\
\hline $\begin{array}{l}\text { Excess carrying } \\
\text { capacity }\end{array}$ & 139 & 61.5 \\
\hline
\end{tabular}

Table 5 shows that the common shortcomings are: - lack of cleaning service, there aren't enough and appropriate toilets on the beaches, the beaches' leaseholder doesn't take into account the carrying capacity of the place and the lack of the security.

Table (6) the unwanted behavior of tourists on the beaches

\begin{tabular}{|l|c|c|}
\hline \multicolumn{1}{|c|}{ Unwanted behavior } & Respondents & $\%$ \\
\hline $\begin{array}{l}\text { Walking with } \\
\text { swimsuits on the public } \\
\text { street }\end{array}$ & 182 & 80.3 \\
\hline Harassment of women & 144 & 63.5 \\
\hline $\begin{array}{l}\text { Using whic } \\
\text { transportation of } \\
\text { wearing wet clothes }\end{array}$ & 146 & 64.4 \\
\hline $\begin{array}{l}\text { Accumulation } \\
\text { garbage }\end{array}$ & 193 & 85.2 \\
\hline $\begin{array}{l}\text { Taking cooking utensils } \\
\text { on the beach }\end{array}$ & 144 & 63.5 \\
\hline
\end{tabular}

According to table 6 the common complaints were concerning the accumulation of garbage, walking with swimsuits on the street, women harassment, taking cooking utensils on the beach and using public transportation while wearing wet clothes. 
Table (7) Troubles faced by residents as a result of overtourism

\begin{tabular}{|l|c|c|}
\hline \multicolumn{1}{|c|}{$\begin{array}{c}\text { Damages afflict the } \\
\text { residents }\end{array}$} & Respondents & $\%$ \\
\hline Traffic congestion & 198 & 87.6 \\
\hline $\begin{array}{l}\text { Pressure on } \\
\text { infrastructure (Sewage } \\
\text { - Electricity - Roads - } \\
\text { Transportation, ...etc.) }\end{array}$ & 137 & 60.6 \\
\hline Lack of freedom & 115 & 50.9 \\
\hline Alienation of residents & 140 & 61.9 \\
\hline Noise & 108 & 47.8 \\
\hline
\end{tabular}

According to the above table, the domestic beach tourism movement in the city contributes to the two major troubles associated with overtourism which have been identified by WTTC (2017), which are: the alienation of residents and overloaded infrastructure. The troubles are related to the environmental effects of overtourism which are fundamentally the result of the increased usage of resources and infrastructure and these effects vary from pollution and damage to congestion as mentioned by Peeters et al. (2018).

Table (8) Suggestions to reduce the negative effects of beach tourism

\begin{tabular}{|c|c|c|}
\hline Suggestions & Respondents & \% \\
\hline $\begin{array}{c}\text { Offering better cleaning } \\
\text { service all day }\end{array}$ & 163 & 72.1 \\
\hline $\begin{array}{c}\text { Providing more litter boxes } \\
\text { on the beaches }\end{array}$ & 152 & 67.3 \\
\hline $\begin{array}{c}\text { Providing more security } \\
\text { guards }\end{array}$ & 147 & 65 \\
\hline $\begin{array}{c}\text { Placing a police car in front } \\
\text { of beaches }\end{array}$ & 117 & 51.8 \\
\hline
\end{tabular}

Table 8 shows that the first three suggestions are more important than the fourth one, these are: offering better cleaning service, providing more litter boxes, as well as security guards on each beach.
Second, regarding the interview conducted, with respect to the first axis; the head of the Administration Center for Tourism and Summer Resorts confirmed that there is a contract with a private cleaning company, which is responsible for the cleanliness of the beaches daily, in addition to the employees of beach leaseholders. He added that the beaches are thoroughly cleaned at the beginning and end of the day, but during the day only the back is cleaned because the workers are accused of theft and blackmail by some visitors. Additionally, he pointed out that there is periodic environmental monitoring of all beaches by the center.

Moreover, he highlighted that there are retired officers recruited to counter any dispute or fight that happens on the beaches. In addition, there are periodic follow-up campaigns to monitor leaseholders 'infractions in relation to prices and to ensure that they are committed to the lease contract. The head of the Central Administration finds that cooperation with a private security services to prevent unwanted behaviors from visitors is very difficult to implement because of the insufficient funding.

Regarding the second axis which focuses on the way complaints are handled, the interviewee proved that there is a complaints number announced on the administration's Facebook page to receive complaints from visitors that is handled immediately.

As for the third axis, the head of the Central Administration stated that there is a vision to conduct awareness campaigns through the various means of media to raise awareness among beach's visitors during summer through cooperation between the Central Administration, the University of Alexandria (With the participation of students) and some social leaders. Besides, the organization 
intends to distribute flyers at Alexandria entrance gates which include all information related to beaches and codes of conduct that should be followed on the beaches to eliminate the unwanted behavior and help them in obtaining a distinctive experience while respecting the privacy of local residents.

In general, the interviewee emphasized the necessity of increasing the awareness campaigns through the mass media which is the first step towards solving the problems associated with the unwanted behavior of domestic tourists. It is also highlighted that a website of the central administration is being designed to announce all information related to the domestic tourists.

Finally, regarding the fourth axis, he confirmed that determining the carrying capacity of beaches is an unfeasible solution to solve the problem of beaches' congestion in Alexandria because it is the nearest coastal city to many rural cities and it is considered a local destination for domestic tourists as (Orabi, 2017) indicated. Therefore, no visitor (local resident or domestic tourist) can be prevented from entering the beach for any reason. This final result corresponds with the opinion of Coldwell (2017), who proved that some solutions are unacceptable in some destinations but are acceptable in others.

\section{Conclusion\& Recommendations}

Overtourism is a phenomenon that has spread in many popular destinations. It has also become a feature of the summer in Alexandria. This is because it is the nearest coastal city to many rural cities which are the main tourist markets. The city's mental image is closely related to beach tourism for domestic tourists.
There are common unwanted behaviors of domestic tourists that have been observed continuously during the summer months, whether on the beaches or on public roads, Consequently, most of the Alexandrians spent their summer vacations outside the city. But generally, the residents suffer from many shortcomings and problems generally or on the beaches. Although some positive steps were taken from the central Administration to improve the situation of beach tourism in Alexandria during summer including the laugh of awareness campaigns and provide sufficient security on the beaches, further effort needs to be exerted to reduce the problems of the residents and restore the charm of Alexandria during summer.

Thus, based on the literature review and the results of the field study, some recommendations could be directed to the Administration Center for Tourism and Summer Resorts, as follows:

- Imposing more restrictions on leaseholders of private and touristic beaches.

- Developing a long-term strategic plan to boost the sustainable development of Alexandria beaches.

- Creating cooperation with tourism and non-tourism organizations (Ministry of Tourism - Ministry of Environment Egyptian Tourist Authority).

- Implementing campaigns to promote Alexandria as a destination that includes many various tourist attractions and offers many recreational activities.

- Increasing the awareness campaigns to encourage local tourists to preserve the city and respect the privacy of local people. 
- Imposing financial penalties on all unwanted behaviors within the beach.

- Providing the beaches with more security, appropriate public services and garbage boxes.

\section{References:}

- Alexandria Portal (2014), Beaches of Alexandria. Available from: http://www.alexandria.gov.eg/Alex/english/be aches.html (Accessed on 3/2/2021).

- Almeida, M., Millán, F. \& Yi, L. (2019), Are Social Media Data Pushing Overtourism?:The Case of Barcelona and Chinese Tourists.

- Coldwell, W. (2017), First Venice and Barcelona: now anti-tourism marches spread across Europe.

- Frihy, O., Dewidar, Kh. \& E1 Raey, M. (1996), Evaluation of coastal problems at Alexandria, Egypt, Ocean \& Coastal Management, Vol. 30, Nos 2-3. pp. 281-295, Elsevier.

- Goodwin, H. (2017), The challenge of Overtourism, Responsible Tourism Partnership Working Paper 4.

- Hussein RA, Abd El-Aziz MY, Arafa AK, ElSebaie OD. (2013), Impact of Alexandria Corniche Road Widening on Mediterranean Sea Water Quality, Egypt. Bull. HIPH. 43 (2):175-184.

- Martín, J., Martínez, J. \& Fernández, J. (2018), An Analysis of the Factors behind the Citizen's Attitude of Rejection towards Tourism in a Context of Overtourism and Economic Dependence on This Activity.

- Martins, M. (2018), Tourism Planning and Tourism phobia: An Analysis of the Strategic Tourism Plan of Barcelona 2010-2015, Journal of Tourism, Heritage \& Services Marketing, Volume 4, Issue 1, pp. 3-7.

- Milano, C., Cheer, J. \& Novelli, M. (2018), Overtourism: a growing global problem, ResearchGate.

- Milano, C., Novelli, M. \& Cheer, J. (2019): Overtourism and Tourism phobia: A Journey Through Four Decades of Tourism Development, Planning and Local Concerns, Tourism Planning \& Development.

- Orabi, R. (2017), Measuring tourism carrying capacity as an effective planning tool for sustainable tourism development: Applied on coastal tourism in Alexandria's city, Published $\mathrm{PhD}$ thesis, Faculty of tourism and hotels, Alexandria University.

- Peeters, P., Gössling, S., Klijs, J., Milano, C., Novelli, M., Dijkmans, C., Eijgelaar, E., Hartman, S., Heslinga, J., Isaac, R., Mitas, O., Moretti, S., Nawijn, J., Papp, B. and Postma, A. (2018), Research for TRAN Committee Overtourism: impact and possible policy responses, European Parliament, Policy Department for Structural and Cohesion Policies, Brussels.

- Prabpriree, M., Maneenetr, T., Siriwong, P. \&Yaipool, K. (2016), Implementing Sustainable Beach Tourism Management Framework for the Royal Coast Cluster, Thailand, Asian Social Science, Vol. 12, No. 8.

- Stanchev, R. \& Turisme, G. (2018), The most affected European destinations by overtourism.

- $\quad$ Sziva, I, B., Smith, M., Olt, G. and Berezvai, Z. (2019) Overtourism and the night-time economy: a case study of Budapest, international journal of tourism cities, Vol. 5(1), pp. 1-16.

- Taiminen, S. (2018), The negative impacts of overtourism on tourism destination from environmental and socio-cultural perspectives, Degree Thesis, International Business.

- Weber, F., Stettler, J., Priskin, J., Taufer, B., Ponnapureddy, S., Fux. C, Camp, M., and Barth, M. (2017), Tourism destinations under pressure: Challenge and innovative solutions, Lucerne University of Applied Sciences and Arts, 6002 Lucerne, Switzerland.

- Where is Map (2020) Where is Alexandria, Egypt located? Available from: https://whereismap.net/where-is-alexandriaegypt-located-what-country-is-alexandria-inalexandria-map/(accessed on 16/1/2020)

- $\quad$ WTTC (2017), Coping with success managing overcrowding in tourism destinations. Available from: https://www.wttc.org (accessed on 16/1/2020) 